University of Nebraska - Lincoln

DigitalCommons@University of Nebraska - Lincoln

USGS Staff -- Published Research

US Geological Survey

2011

\title{
What Do We Know About Metal Recycling Rates?
}

T. E. Graedel

Yale University, thomas.graedel@yale.edu

Julian Allwood

Cambridge University

Jean-Pierre Birat

Maizieres-les-Metz

Matthias Buchert

Öko Institut

Christian Hagelüken

Umicore Precious Metals

See next page for additional authors

Follow this and additional works at: https://digitalcommons.unl.edu/usgsstaffpub

Graedel, T. E.; Allwood, Julian; Birat, Jean-Pierre; Buchert, Matthias; Hagelűken, Christian; Reck, Barbara K.; Sibley, Scott F.; and Sonnemann, Guido, "What Do We Know About Metal Recycling Rates?" (2011). USGS Staff -- Published Research. 596.

https://digitalcommons.unl.edu/usgsstaffpub/596

This Article is brought to you for free and open access by the US Geological Survey at DigitalCommons@University of Nebraska - Lincoln. It has been accepted for inclusion in USGS Staff -- Published Research by an authorized administrator of DigitalCommons@University of Nebraska - Lincoln. 


\section{Authors}

T. E. Graedel, Julian Allwood, Jean-Pierre Birat, Matthias Buchert, Christian Hagelüken, Barbara K. Reck, Scott F. Sibley, and Guido Sonnemann 


\title{
What Do We Know About Metal Recycling Rates?
}

\author{
T. E. Graedel, Julian Allwood, Jean-Pierre Birat, Matthias \\ Buchert, Christian Hagelüken, Barbara K. Reck, Scott F. Sibley, \\ and Guido Sonnemann
}

\section{Keywords:}

end-of-life recycling rate (EOL-RR) industrial ecology old scrap ratio (OSR) recycled content $(R C)$ recycling input rate (RIR) recycling metrics

:// Supporting information is available on the JIE Web site

\author{
Address correspondence to: \\ Dr. Thomas E. Graedel \\ School of Forestry and Environmental \\ Studies \\ Yale University \\ 195 Prospect Street \\ New Haven, CT 06511 \\ thomas.graedel@yale.edu \\ (C) 2011 by Yale University \\ DOI: $10.1111 / \mathrm{j} .1530-9290.2011 .00342 . x$
}

Volume 15, Number 3

\section{I}

\section{Summary}

The recycling of metals is widely viewed as a fruitful sustainability strategy, but little information is available on the degree to which recycling is actually taking place. This article provides an overview on the current knowledge of recycling rates for 60 metals. We propose various recycling metrics, discuss relevant aspects of recycling processes, and present current estimates on global end-of-life recycling rates (EOL-RR; i.e., the percentage of a metal in discards that is actually recycled), recycled content (RC), and old scrap ratios (OSRs; i.e., the share of old scrap in the total scrap flow). Because of increases in metal use over time and long metal in-use lifetimes, many RC values are low and will remain so for the foreseeable future. Because of relatively low efficiencies in the collection and processing of most discarded products, inherent limitations in recycling processes, and the fact that primary material is often relatively abundant and low-cost (which thereby keeps down the price of scrap), many EOL-RRs are very low: Only for 18 metals (silver, aluminum, gold, cobalt, chromium, copper, iron, manganese, niobium, nickel, lead, palladium, platinum, rhenium, rhodium, tin, titanium, and zinc) is the EOL-RR above 50\% at present. Only for niobium, lead, and ruthenium is the RC above $50 \%$, although 16 metals are in the $25 \%$ to $50 \%$ range. Thirteen metals have an OSR greater than 50\%. These estimates may be used in considerations of whether recycling efficiencies can be improved; which metric could best encourage improved effectiveness in recycling; and an improved understanding of the dependence of recycling on economics, technology, and other factors.

This article is a U.S. government work, and is not subject to copyright in the United States. 


\section{Introduction and Scope of Study}

Metals are uniquely useful materials by virtue of their fracture toughness, thermal and electrical conductivity, and performance at high temperatures, among other properties. For these reasons, they are used in a wide range of applications in areas such as machinery, energy, transportation, building and construction, information technology, and appliances. Additionally, of the various resources seeing wide use in modern technology, metals are different from other materials in that they are inherently recyclable. This means that, in theory, they can be used over and over again, which minimizes the need to mine and process virgin materials and thus saves substantial amounts of energy and water while limiting environmental degradation in the process.

Recycling data have the potential to demonstrate how efficiently metals are being reused and can thereby serve some of the following purposes:

- Determine the influence of recycling on resource sustainability

- Provide information to governments, the metals industry, metal users, and the recycling industry on recycling rates and opportunities for change

- Provide information for research on improving recycling efficiency

- Provide information for life cycle assessments

- Stimulate informed recycling policies.

This article summarizes the results of a working group of the United Nations Environment Programme's (UNEP's) International Panel for Sustainable Resource Management (Resource Panel) on metal recycling rates. We discuss definitions of recycling statistics, review recycling information, identify information gaps, and discuss the implications of our results. The goal is to summarize available information (rather than to generate new data), highlight information gaps, and fill these gaps through informed estimates.

The elements investigated are not all metals, according to the chemical meaning of metal, as metalloids ${ }^{1}$ have been included, whereas the radioactive actinides and polonium are excluded.
From the alkali metals only lithium ( $\mathrm{Li}$ ) has been included because of its use in batteries, and from the alkaline metals all but calcium have been included. Furthermore, selenium has been included because of its importance as an alloying element and semiconductor. The selected elements (called "metals" hereafter) include the following:

- Group 1: vanadium (V), chromium (Cr), manganese $(\mathrm{Mn})$, iron $(\mathrm{Fe})$, nickel $(\mathrm{Ni})$, niobium ( $\mathrm{Nb}$ ), molybdenum (Mo)

- Group 2: magnesium (Mg), aluminum (Al), titanium $(\mathrm{Ti})$, cobalt $(\mathrm{Co})$, copper $(\mathrm{Cu})$, zinc $(\mathrm{Zn})$, tin $(\mathrm{Sn})$, lead $(\mathrm{Pb})$

- Group 3: ruthenium $(\mathrm{Ru})$, rhodium $(\mathrm{Rh})$, palladium $(\mathrm{Pd})$, silver $(\mathrm{Ag})$, osmium $(\mathrm{Os})$, iridium (Ir), platinum $(\mathrm{Pt})$, gold $(\mathrm{Au})$

- Group 4: lithium (Li), beryllium (Be), boron (B), scandium (Sc), gallium (Ga), germanium (Ge), arsenic (As), selenium (Se), strontium $(\mathrm{Sr})$, yttrium $(\mathrm{Y})$, zirconium $(\mathrm{Zr})$, cadmium $(\mathrm{Cd})$, indium (In), antimony (Sb), tellurium (Te), barium $(\mathrm{Ba})$, lanthanum $(\mathrm{La})$, cerium $(\mathrm{Ce})$, praseodymium $(\mathrm{Pr})$, neodymium $(\mathrm{Nd})$, samarium $(\mathrm{Sm})$, europium $(\mathrm{Eu})$, gadolinium $(\mathrm{Gd})$, terbium $(\mathrm{Tb})$, dysprosium (Dy), holmium (Ho), erbium (Er), thulium (Tm), ytterbium (Yb), lutetium (Lu), hafnium (Hf), tantalum (Ta), tungsten (W), rhenium $(\mathrm{Re})$, mercury $(\mathrm{Hg})$, thallium $(\mathrm{Tl})$, bismuth (Bi).

For our purpose, the metals are designated as ferrous metals (Group 1), nonferrous metals (Group 2), precious metals (Group 3), and specialty metals (Group 4). The principal metals in each of these groupings are more or less according to popular use, but the less abundant or less widely used elements are not necessarily readily categorized (e.g., tellurium [Te] could equally well have been included in the ferrous metals).

Metals are predominantly used in alloy form, but not always, and recycling information that specifies the form of the metal is not commonly available. Thus, all information herein refers to the aggregate of the many forms of the metal in question (but as metal, rather than generally in a nonmetallic form such as a sulfate or oxide, e.g., barium sulfate $\left[\mathrm{BaSO}_{4}\right]$, titanium dioxide 


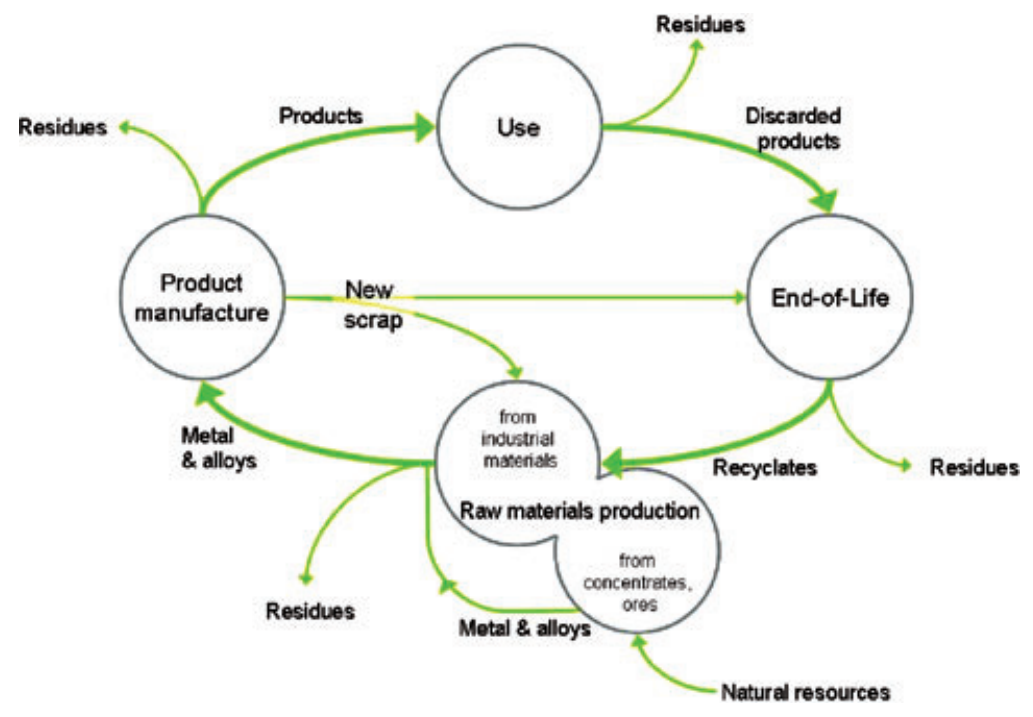

Figure I The life cycle of a metal, consisting of production, product manufacture, use, and end of life. The loss of residues at each stage and the reuse of scrap are indicated. (After Meskers 2008.)

$\left.\left[\mathrm{TiO}_{2}\right]\right)$. This distinction is addressed in the results where necessary.

\section{Metal Recycling Considerations}

\section{Metal Life Cycle}

Figure 1 illustrates a simplified metal and product life cycle. The cycle is initiated by choices in product design: which materials are going to be used, how they will be joined, and which processes are used for manufacturing. Choices made during design have a lasting effect on material and product life cycles. They drive the demand for specific metals and influence the effectiveness of the recycling chain during end of life (EOL). The finished product enters the use phase and becomes part of the in-use stock of metals. When a product is discarded, it enters the EOL phase. It is separated into different metal streams (recyclates $^{2}$ ), which have to be suitable for raw materials production to ensure that the metals can be successfully recycled. In each phase of the life cycle metal losses occur, indicated by the "residues" arrow in figure 1.

The life cycle of a metal is closed if EOL products are entering appropriate recycling chains, which leads to scrap metal in the form of recyclates displacing primary metals. The life cycle is open if EOL products neither are collected for recycling nor enter those recycling streams that are capable of recycling the particular metal efficiently. Open life cycles occur as a result of products discarded to landfills, products recycled through inappropriate technologies (e.g., the informal sector) whereby metals are not or only inefficiently recovered, and metal recycling in which the functionality (i.e., the physical and chemical properties) of the EOL metal is lost (nonfunctional or "open-loop" recycling; see below). A related distinction between open and closed material systems is made in life cycle assessment (ISO 2006), in which a material system is only considered closed when a material is recycled into the same use (Dubreuil et al. 2010).

\section{Scrap Types and Types of Recycling}

The different types of recycling are related to the type of scrap and its treatment:

- Home scrap is material generated during material production or during fabrication or manufacturing that can be directly reinserted in the process that generated it. 
Home scrap recycling is generally economically beneficial and easy to accomplish. It is excluded from recycling statistics and not further discussed here.

- New (or preconsumer) scrap (sometimes termed "prompt scrap") also originates from a fabrication or manufacturing process. As opposed to home scrap, it is not recycled within the same facility but rather is transferred to the scrap market. Because of its known properties, high purity, and value, its recycling is generally economically beneficial and easy to accomplish, although recycling becomes more difficult the closer one gets to finished products (e.g., rejected printed circuit boards). New scrap is typically included in recycling statistics.

- Old (or postconsumer) scrap is metal in products that have reached their EOL. Their recycling requires more effort, particularly when the metal is a small part of a complex product.

- Functional recycling ${ }^{3}$ is that portion of EOL recycling in which the metal in a discarded product is separated and sorted to obtain recyclates that are returned to raw material production processes that generate a metal or metal alloy. Often it is not the specific alloy that is remelted to make the same alloy but any alloys within a certain class of alloys that are remelted to make one or more specific alloys. For example, a mixture of austenitic stainless steel alloys might be remelted and the resulting composition adjusted by addition of reagents or virgin metal to make a specific stainless steel grade.

- Nonfunctional recycling is that portion of EOL recycling in which the metal is collected as old metal scrap and incorporated in an associated large-magnitude material stream as a "tramp" or impurity elements. This prevents dissipation into the environment but represents the loss of the metal's function, as it is generally impossible to recover it from the large-magnitude stream. Although nonfunctional recycling is here termed a type of recycling, it leads to an open metal life cycle, as discussed above. Examples are small amounts of copper in iron recyclates that are incorporated into recycled carbon steel.

- Losses occur when metal is not completely captured through any of the recycling streams mentioned above. Losses also result from in-use dissipation, as in the corrosion of sacrificial zinc coatings on steel, loss of the metallic contents of vehicle brake linings, and unrecovered metal in mine tailings and refinery slags. Dissipation, tailings, and slag losses are not reflected in any of the recycling rate statistics in the present work.

\section{Defining Recycling Statistics}

Recycling rates have been defined in many different ways, for many life stages; sometimes the term is left undefined. Attempts to rectify this situation (e.g., Sibley and Butterman 1995; Sibley 2004; Eurometaux 2006; Bailey et al. 2008; Reck and Gordon 2008; Dubreuil et al. 2010) have suggested more consistent approaches. In this article, we build on that work to define recycling efficiencies at EOL (collection, process efficiency, recycling rate) and in metal production (recycling input rate, recycled content, old scrap ratio).

At EOL, the recycling efficiency of a metal can be measured at three levels:

1. How much of the EOL metal contained in various discarded products is collected and enters the recycling chain (as opposed to metal that is landfilled)? (Old scrap collection rate $[\mathrm{CR}])$.

2. What is the efficiency in any given recycling process (i.e., the yield)? (Recycling process efficiency rate, also called recovery rate; e.g., Van Schaik et al. 2004).

3. What is the EOL recycling rate (EOL-RR)? The EOL-RR always refers herein to functional recycling (unless noted differently) and includes recycling as a pure metal (e.g., copper) and as an alloy (e.g., brass).

In contrast, the nonfunctional EOL-RR describes the amount of metal that is collected but lost for functional recycling and that becomes an impurity or "tramp element" in the dominant metal with which it is collected (e.g., copper in steel; more examples are provided in 


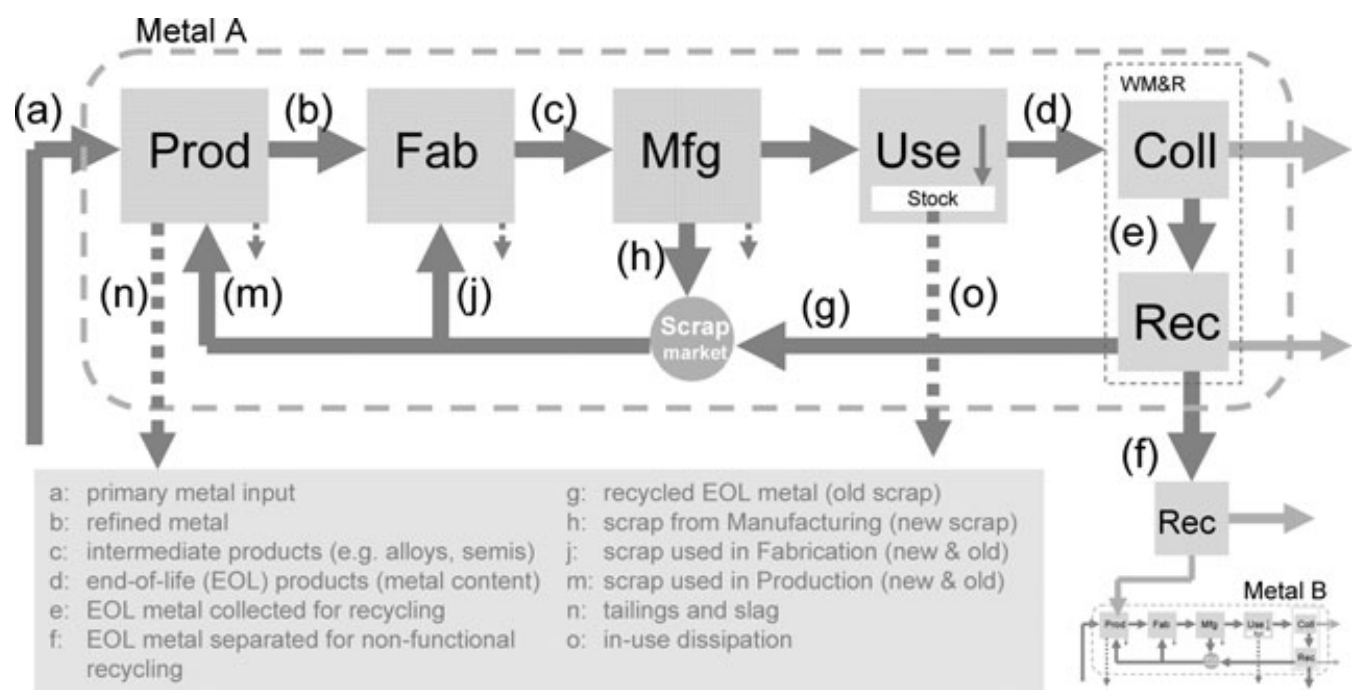

Figure 2 Flows related to a simplified life cycle of metals and the recycling of production scrap and end-of-life products. Boxes indicate the main processes (life stages): Prod = production; Fab = fabrication; Mfg = manufacturing; WM\&R = waste management and recycling; Coll = collection; Rec = recycling. Yield losses at all life stages are indicated through dashed lines (in waste management [WM] referring to landfills). When material is discarded to WM, it may be recycled (flow e), lost into the cycle of another metal (flow $\mathrm{f}$, as with copper wire mixed into steel scrap), or landfilled. The boundary indicates the global industrial system, not a geographical entity. When metal is nonfunctionally recycled ("downcycled"), it enters the cycle of another metal, indicated by the minicycle in the lower right corner. A more detailed diagram of metal production and fabrication is provided in Appendix $\mathrm{SI}-6$ of the Supporting Information on the Web.

Appendix S1-5 in the Supporting Information on the Web). The EOL-RR is strongly influenced by the least efficient link in the recycling chain, which is typically the initial collection activity.

Figure 2 provides a simplified metal life cycle on the basis of which the above-mentioned EOL metrics can be calculated:

1. Old scrap collection rate: $\mathrm{CR}=\mathrm{e} / \mathrm{d}$

2. Recycling process efficiency rate $=\mathrm{g} / \mathrm{e}$

3. $E O L-R R=g / d$ (refers to functional recycling only). Nonfunctional EOL-RR $=\mathrm{f} / \mathrm{d}$

In metal production, two other metrics are of importance: the recycling input rate (RIR) and the old scrap ratio (OSR). The RIR describes the fraction of secondary (scrap) metal in the total metal input of metal production-that is, flow c in figure 2 (as an approximation, primary metal input is calculated as extracted ore minus losses through tailings). The RIR is identical to the recycled content (RC) when the latter is calculated as follows (see Appendix S1-6 in the Supporting Information on the Web for further details).

$$
\text { 4. } \mathrm{RC}=(j+m) /(a+j+m)
$$

The calculation of RC is straightforward at the global level but difficult, if not impossible, at the country level. The reason is that information on the recycled content of imported produced metals is typically not available (flow b; i.e., the share of $\mathrm{m} /(\mathrm{a}+\mathrm{m})$ in other countries is unknown), which in turn makes a precise calculation of the recycled content of flow c impossible.

The OSR describes the fraction of old scrap $(\mathrm{g})$ in the recycling flow $(\mathrm{g}+\mathrm{h})$.

5. OSR $=(g) /(g+h)$

In combination with the recycled content, this metric reveals the quantity of metal from EOL products used again for metal production and product manufacturing and enhances understanding of the degree to which the use of 
scrap from various stages of the metal life cycle is occurring.

For a better interpretation of these metrics, we have to consider some influencing factors. The recycled content of metals depends on the amount of scrap available and on the scrap quality: The new-scrap availability depends on the degree of metal use and the process efficiency in fabrication and manufacturing. The old-scrap availability is a function of metal use a product lifetime ago, in-use dissipation over the product lifetime, and the efficiency of the EOL collection and recycling system. High growth rates in metal demand in the past, together with long product lifetimes (often several decades), result in available old-scrap quantities that are typically much smaller than the metal demand in production, which leads to RCs much smaller than $100 \%$. Even a very efficient EOL recycling system would not provide enough old scrap for a high recycled content with a high OSR in this circumstance. Comparisons of RCs across metals are problematic due to different growth rates in metal use over time, different end uses with different respective lifetimes and different in-use dissipation rates, different production processes (which sometimes limit the amount of scrap used), and varying tolerances in metal production to scrap impurities (Van Schaik et al. 2004; Gaustad et al. 2010). The recycling process efficiency varies from metal to metal, depending on the metal or grade for which a process is optimized, and although it can be high it will never reach $100 \%$ due to thermodynamic and other limitations (Castro et al. 2004).

It is also important to note that recycling efficiency is highly product-specific. The form in which a metal is used (pure, alloyed, etc.), the quantity of a metal in a specific product, the design of a product (easy or hard to disassemble), and the monetary value of the metal all play a role. Scholarly studies that demonstrate these dependencies are rare-exceptions include the work of Van Schaik (2004) and Van Schaik and colleagues (2004) for automobiles and Chancerel and Rotter (2009) for electronics. Additional information can be found on industry group Web sites (e.g., Steel Recycling Institute 2010 for steel and International Copper Study Group 2004 for vehicles). Overall, how- ever, the available product-specific sources do not treat very many sectors, products, or metals of interest, and, with the exception of the precious metals (see Appendix S1-3 in the Supporting Information on the Web), we are unable to address product sector-specific recycling rates in this study.

\section{Consensus Recycling Statistics}

The set of global-average metal recycling statistics that we derive represents an order of magnitude estimate that was drawn from a review of the recycling literature and informed estimates by industry experts. The years for which figures are available vary, but many apply to the 2000 2005 time period. This literature review was followed by a workshop 4 in which experts discussed the relevance and accuracy of the published information, which is clearly of varying quality and differs by region, product, and available technology, all of which make it challenging to quote definitive values for any of the recycling metrics. For used or EOL electronics, automotive vehicles, and some other products, significant exports take place from industrialized to transition and developing countries, where the recycling process efficiency rate is often low. Additionally, for the base metals ${ }^{5}$ and gold, especially, informal recycling in developing countries is extensive. Thus, no attempt was made to specify exact recycling rates; rather, the experts chose five ranges for recycling values in cases where familiarity with the recycling industry enabled such choices to be made, even in the absence or paucity of published data. Because of the independence of data sources and the underlying uncertainties, mass balance cannot always be achieved when one combines the results of the various metrics, nor should one expect to do so, and the consensus numbers compiled here by the experts need to be understood as a first comprehensive assessment that will require further review and elaboration over time. Nonetheless, we regard the magnitudes of the results to be approximately correct on a global average basis as of the time of publication of this article.

The detailed results of these exercises are presented in the Appendixes in the Supporting Information on the Web. The three periodic 


\begin{tabular}{|c|c|c|c|c|c|c|c|c|c|c|c|c|c|c|c|c|c|c|}
\hline $\begin{array}{l}1 \\
\mathrm{H}\end{array}$ & & & & & & & & & & & & & & & & & & $\begin{array}{c}2 \\
\mathrm{He}\end{array}$ \\
\hline 3 & $\mathrm{Be}$ & & & & & & & & & & & & B & $\begin{array}{l}6 \\
\mathrm{C}\end{array}$ & $\begin{array}{l}7 \\
\mathrm{~N}\end{array}$ & $\begin{array}{l}8 \\
0\end{array}$ & $\begin{array}{l}9 \\
F\end{array}$ & $\begin{array}{l}10 \\
\mathrm{Ne}\end{array}$ \\
\hline $\begin{array}{l}11 \\
\mathrm{Na}\end{array}$ & $\begin{array}{c}12 \\
\mathrm{Mg}\end{array}$ & & & & & & & & & & & & $\begin{array}{l}13 \\
\mathrm{Al}\end{array}$ & $\begin{array}{c}14 \\
\mathrm{Si}\end{array}$ & $\begin{array}{c}15 \\
\mathrm{P}\end{array}$ & $\begin{array}{c}16 \\
\mathbf{S}\end{array}$ & $\begin{array}{l}17 \\
\mathrm{Cl}\end{array}$ & $\begin{array}{l}18 \\
\mathrm{Ar}\end{array}$ \\
\hline $\begin{array}{l}19 \\
\mathrm{~K}\end{array}$ & $\begin{array}{l}20 \\
\mathrm{Ca}\end{array}$ & Sc & $\begin{array}{l}22 \\
\mathrm{Ti}\end{array}$ & $\begin{array}{l}23 \\
\mathrm{~V}\end{array}$ & $\begin{array}{l}2 \\
\text { C }\end{array}$ & $\stackrel{2}{\mathrm{~N}}$ & & $\begin{array}{l}26 \\
\mathrm{Fe}\end{array}$ & $\begin{array}{l}27 \\
\text { Co }\end{array}$ & $\begin{array}{l}28 \\
\mathrm{Ni}\end{array}$ & $\begin{array}{l}29 \\
\mathrm{Cu}\end{array}$ & $\begin{array}{l}30 \\
\mathrm{Zn}\end{array}$ & $\mathrm{Ga}$ & $\mathrm{Ge}$ & As & Se & $\begin{array}{l}35 \\
\mathrm{Br}\end{array}$ & $\begin{array}{l}36 \\
\mathrm{Kr}\end{array}$ \\
\hline $\begin{array}{l}37 \\
\mathrm{Rb}\end{array}$ & $\mathrm{Sr}$ & $\begin{array}{l}39 \\
Y\end{array}$ & $\begin{array}{l}40 \\
\mathrm{Zr}\end{array}$ & $\begin{array}{l}41 \\
\mathrm{Nb}\end{array}$ & $\begin{array}{l}4 \\
M\end{array}$ & $\begin{array}{l}4 \\
T\end{array}$ & & & $\begin{array}{l}45 \\
\mathrm{Rh}\end{array}$ & $\begin{array}{l}46 \\
\mathrm{Pd}\end{array}$ & $\begin{array}{l}47 \\
\mathrm{Ag}\end{array}$ & $\mathrm{CA}$ & In & $\begin{array}{l}50 \\
\text { Sn }\end{array}$ & $\mathrm{Sb}$ & $\mathrm{Te}$ & $\begin{array}{c}53 \\
1\end{array}$ & $\begin{array}{l}54 \\
\times e\end{array}$ \\
\hline $\begin{array}{l}55 \\
\text { Cs }\end{array}$ & $\begin{array}{l}56 \\
\mathrm{Ba}\end{array}$ & * & $\begin{array}{l}72 \\
\mathrm{Hf}\end{array}$ & 73 & & $\begin{array}{l}7 \\
\mathrm{R}\end{array}$ & & Os & $\begin{array}{l}77 \\
\text { Ir }\end{array}$ & $\begin{array}{l}78 \\
\mathrm{Pt}\end{array}$ & $\begin{array}{l}79 \\
\mathrm{Au}\end{array}$ & $\mathrm{Hg}$ & 81 & $\begin{array}{l}82 \\
\mathrm{~Pb}\end{array}$ & 83 & $\begin{array}{l}84 \\
\text { Po }\end{array}$ & $\begin{array}{l}85 \\
\text { At }\end{array}$ & $\begin{array}{l}86 \\
\mathrm{Rn}\end{array}$ \\
\hline $\begin{array}{l}87 \\
\mathrm{Fr}\end{array}$ & $\begin{array}{l}88 \\
\mathrm{Ra}\end{array}$ & ** & $\begin{array}{c}104 \\
\mathrm{Rf}\end{array}$ & $\begin{array}{l}105 \\
\mathrm{Db}\end{array}$ & $\begin{array}{c}10 \\
\mathrm{~S}\end{array}$ & $\begin{array}{l}10 \\
B\end{array}$ & & $\begin{array}{c}108 \\
\mathrm{Hs}\end{array}$ & $\begin{array}{c}109 \\
\mathrm{Mt}\end{array}$ & $\begin{array}{l}110 \\
\text { Ds }\end{array}$ & $\begin{array}{l}111 \\
\mathrm{Rg}\end{array}$ & $\begin{array}{l}112 \\
\text { Uub }\end{array}$ & $\begin{array}{l}113 \\
\text { Uut }\end{array}$ & $\begin{array}{c}114 \\
\text { Uuq }\end{array}$ & $\begin{array}{l}115 \\
\text { Uup }\end{array}$ & $\begin{array}{l}116 \\
\text { Uuh }\end{array}$ & $\begin{array}{l}\text { (117) } \\
\text { (Uus) }\end{array}$ & $\begin{array}{l}118 \\
\text { Uuo }\end{array}$ \\
\hline
\end{tabular}

\begin{tabular}{|c|c|c|c|c|c|c|c|c|c|c|c|c|c|c|c|}
\hline * Lanthanides & 57 & $\mathrm{Ce}$ & $\begin{array}{l}59 \\
\mathrm{Pr}\end{array}$ & $\mathrm{Nd}$ & $\begin{array}{l}61 \\
\mathrm{Pm}\end{array}$ & Sm & $\begin{array}{l}63 \\
\text { Eu }\end{array}$ & Gd & Tb & Dy & $\begin{array}{l}67 \\
\mathrm{Ho}\end{array}$ & $\begin{array}{l}68 \\
\mathrm{Er}\end{array}$ & 69 & Yo & $\mathrm{Lu}$ \\
\hline & $\begin{array}{l}89 \\
\text { Ac }\end{array}$ & $\begin{array}{l}90 \\
\text { Th }\end{array}$ & $\begin{array}{l}91 \\
\mathrm{~Pa}\end{array}$ & $\begin{array}{l}92 \\
\mathrm{U}\end{array}$ & $\begin{array}{l}93 \\
\mathrm{~Np}\end{array}$ & $\begin{array}{l}94 \\
\mathrm{Pu}\end{array}$ & $\begin{array}{c}95 \\
\mathrm{Am}\end{array}$ & $\begin{array}{c}96 \\
\mathrm{Cm}\end{array}$ & $\begin{array}{l}97 \\
\mathrm{Bk}\end{array}$ & $\begin{array}{l}98 \\
\mathrm{Cf}\end{array}$ & $\begin{array}{l}99 \\
\text { Es }\end{array}$ & $\begin{array}{l}100 \\
\mathrm{Fm}\end{array}$ & $\begin{array}{l}101 \\
\text { Md }\end{array}$ & $\begin{array}{l}102 \\
\text { No }\end{array}$ & $\begin{array}{c}103 \\
\mathrm{Lr}\end{array}$ \\
\hline
\end{tabular}

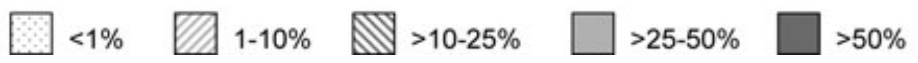

Figure 3 The periodic table of global average end-of-life functional recycling rates (EOL-RR) for 60 metals, with the individual metals categorized into one of five ranges. Unshaded entries indicate that no data or estimates are available or that the elements were not addressed in this study. These evaluations do not consider metal emissions from coal power plants.

table displays in figures 3, 4, and 5 illustrate the consensus results in compact visual display formats.

The EOL-RR results in figure 3 relate to whatever form (pure, alloy, etc.) in which substancespecific recycling occurs. To reflect the level of certainty of the data and the estimates, data are divided into five bins: greater than $50 \%, 26 \%$ to $50 \%, 11 \%$ to $25 \%, 1 \%$ to $10 \%$, and less than $1 \%$. It is noteworthy that for only 18 of the 62 metals do we estimate the EOL-RR to be above 50\%, and it was usually barely above that level. Another three metals are in the $26 \%$ to $50 \%$ group, and three more were in the $11 \%$ to $25 \%$ group. For a very large number, little or no EOL recycling is occurring.

Similarly, figure 4 presents the RC data in similar form. Lead, ruthenium, and niobium are the only metals for which RC is greater than $50 \%$, but 16 metals have RC in the $26 \%$ to $50 \%$ range. This reflects a combination in several cases of efficient employment of new scrap as well as better than average EOL recycling.

The OSR results (figure 5) tend to be high for valuable materials, because these materials are used with minimal losses in manufacturing processes and collected at EOL with relatively high efficiency. Collection and recycling at EOL are relatively high as well for the hazardous metals cadmium, mercury, and lead, although significant losses certainly occur for these metals also (e.g., Hawkins et al. 2006). Overall, thirteen metals have OSRs greater than $50 \%$, and another ten have OSRs in the range from $26 \%$ to $50 \%$.

Where relatively high EOL-RRs are derived, the impression might be given that the metals in question are being used more responsibly than those with lower rates. In reality, rates tend to reflect the degree to which materials are used in large amounts in easily recoverable applications (e.g., lead in batteries, steel in automobiles). In contrast, when materials are used in small 


\begin{tabular}{|c|c|c|c|c|c|c|c|c|c|c|c|c|c|c|c|c|c|c|}
\hline $\begin{array}{l}1 \\
\mathrm{H}\end{array}$ & & & & & & & & & & & & & & & & & & $\begin{array}{c}2 \\
\mathrm{He}\end{array}$ \\
\hline $\mathrm{Li}$ & 85 & & & & & & & & & & & & $\begin{array}{l}5 \\
\text { B }\end{array}$ & $\begin{array}{l}6 \\
\mathrm{C}\end{array}$ & $\begin{array}{l}7 \\
\mathrm{~N}\end{array}$ & $\begin{array}{l}8 \\
0\end{array}$ & $\begin{array}{l}9 \\
F\end{array}$ & $\begin{array}{l}10 \\
\mathrm{Ne}\end{array}$ \\
\hline $\begin{array}{l}11 \\
\mathrm{Na}\end{array}$ & $\begin{array}{c}12 \\
\mathrm{Mg}\end{array}$ & & & & & & & & & & & & $\begin{array}{l}13 \\
\mathrm{Al}\end{array}$ & $\begin{array}{l}14 \\
\mathrm{Si}\end{array}$ & $\begin{array}{c}15 \\
\mathbf{P} \\
\end{array}$ & $\begin{array}{c}16 \\
\mathrm{~S}\end{array}$ & $\begin{array}{l}17 \\
\mathrm{Cl}\end{array}$ & $\begin{array}{l}18 \\
\mathrm{Ar}\end{array}$ \\
\hline $\begin{array}{l}19 \\
\mathrm{~K}\end{array}$ & $\begin{array}{l}20 \\
\mathrm{Ca}\end{array}$ & $\begin{array}{l}21 \\
\text { Sc }\end{array}$ & & $\begin{array}{l}23 \\
\mathrm{~V}\end{array}$ & 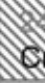 & & & $\begin{array}{l}26 \\
\mathrm{Fe}\end{array}$ & $\begin{array}{l}27 \\
\text { Co }\end{array}$ & $\begin{array}{l}28 \\
\mathrm{Ni}\end{array}$ & at & 21 & & $\begin{array}{l}32 \\
\mathrm{Ge}\end{array}$ & As & se & $\begin{array}{l}35 \\
\mathrm{Br}\end{array}$ & $\begin{array}{l}36 \\
\mathrm{Kr}\end{array}$ \\
\hline $\begin{array}{l}37 \\
\mathrm{Rb}\end{array}$ & $\begin{array}{l}38 \\
\mathrm{Sr}\end{array}$ & $\begin{array}{l}39 \\
Y\end{array}$ & Zs & $\begin{array}{l}41 \\
\mathrm{Nb}\end{array}$ & 42 & & & $\begin{array}{l}44 \\
\mathrm{Ru}\end{array}$ & $\begin{array}{l}45 \\
\mathrm{Rh}\end{array}$ & $\begin{array}{l}46 \\
\mathrm{Pd}\end{array}$ & $\begin{array}{l}47 \\
\mathrm{Ag}\end{array}$ & 120 & $\begin{array}{l}49 \\
\text { In }\end{array}$ & 50. & 54. & $\begin{array}{l}52 \\
\mathrm{Te}\end{array}$ & $\begin{array}{c}53 \\
1\end{array}$ & $\begin{array}{l}54 \\
\times e\end{array}$ \\
\hline $\begin{array}{l}55 \\
\text { Cs }\end{array}$ & $\begin{array}{l}56 \\
\mathrm{Ba}\end{array}$ & * & $\begin{array}{l}72 \\
\mathrm{Hf}\end{array}$ & Na & $\begin{array}{l}74 \\
\text { W }\end{array}$ & & & Os & & $\begin{array}{l}78 \\
\mathrm{Pt}\end{array}$ & $\begin{array}{l}79 \\
\mathrm{Au}\end{array}$ & $\begin{array}{l}80 \\
\mathrm{Hg}\end{array}$ & $\begin{array}{l}81 \\
\mathrm{TI}\end{array}$ & $\begin{array}{l}82 \\
\mathrm{~Pb}\end{array}$ & $\begin{array}{l}83 \\
\mathrm{Bi}\end{array}$ & $\begin{array}{l}84 \\
\text { Po }\end{array}$ & $\begin{array}{l}85 \\
\text { At }\end{array}$ & $\begin{array}{l}86 \\
\mathrm{Rn}\end{array}$ \\
\hline $\begin{array}{l}87 \\
\mathrm{Fr}\end{array}$ & $\begin{array}{l}88 \\
\mathrm{Ra}\end{array}$ & $\star \star \star$ & $\begin{array}{c}104 \\
\text { Rf }\end{array}$ & $\begin{array}{l}105 \\
\mathrm{Db}\end{array}$ & $\begin{array}{l}10 \\
\mathrm{Sc}\end{array}$ & & & $\begin{array}{c}108 \\
\mathrm{Hs}\end{array}$ & $\begin{array}{c}109 \\
\mathrm{Mt}\end{array}$ & $\begin{array}{l}110 \\
\text { Ds }\end{array}$ & $\begin{array}{l}111 \\
\mathrm{Rg}\end{array}$ & $\begin{array}{l}112 \\
\text { Uub }\end{array}$ & $\begin{array}{l}113 \\
\text { Uut }\end{array}$ & $\begin{array}{l}114 \\
\text { Uuq }\end{array}$ & $\begin{array}{l}115 \\
\text { Uup }\end{array}$ & $\begin{array}{l}116 \\
\text { Uuh }\end{array}$ & $\begin{array}{l}\text { (117) } \\
\text { (Uus) }\end{array}$ & $\begin{array}{l}118 \\
\text { Uuo }\end{array}$ \\
\hline
\end{tabular}

\begin{tabular}{|c|c|c|c|c|c|c|c|c|c|c|c|c|c|c|c|}
\hline * Lanthanides & $\mathrm{la}$ & $\mathrm{Co}$ & Pr & Nd & $\begin{array}{l}61 \\
\mathrm{Pm} \\
\end{array}$ & $\begin{array}{l}62 \\
\mathrm{Sm}\end{array}$ & $\begin{array}{ll}63 \\
\mathrm{Eu}\end{array}$ & Gd & $\mathrm{Tb}$ & Dy & Ho & 68 & Tm & Yo & $\mathrm{Lu}$ \\
\hline & $\begin{array}{l}89 \\
\mathrm{AC}\end{array}$ & $\begin{array}{l}90 \\
\text { Th }\end{array}$ & $\begin{array}{l}91 \\
\mathrm{~Pa}\end{array}$ & $\begin{array}{l}92 \\
\mathrm{U}\end{array}$ & $\begin{array}{l}93 \\
\mathrm{~Np}\end{array}$ & $\begin{array}{l}94 \\
\mathrm{Pu}\end{array}$ & $\begin{array}{c}95 \\
\text { Am }\end{array}$ & $\begin{array}{c}96 \\
\mathrm{Cm}\end{array}$ & $\begin{array}{l}97 \\
\text { Bk }\end{array}$ & $\begin{array}{l}98 \\
\text { Cf }\end{array}$ & $\begin{array}{l}99 \\
\text { Es }\end{array}$ & $\begin{array}{l}100 \\
\mathrm{Fm}\end{array}$ & $\begin{array}{l}101 \\
\text { Md }\end{array}$ & $\begin{array}{l}102 \\
\text { No }\end{array}$ & $\begin{array}{c}103 \\
\text { Lr }\end{array}$ \\
\hline
\end{tabular}

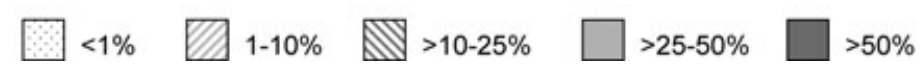

Figure 4 The periodic table of global average recycled content (RC) for 60 metals, with the individual metals categorized into one of five ranges. Unshaded entries indicate that no data or estimates are available or that the elements were not addressed in this study.

quantities in complex products (e.g., tantalum in electronics), recycling is technically much more challenging.

\section{Implications of the Results}

Can recycling efficiencies be improved? That is, can materials cycles be transformed from open (i.e., without comprehensive recycling) to closed (i.e., completely reemployed) or at least to less open than they are at present? A major challenge is that open cycles are typical for many metals in consumer goods, such as cars, electronics, and small appliances (Hagelüken 2007), due to the following:

- Product designs that make disassembly and material separation difficult or impossible.

- A high mobility of products and the unclear material flows that result. These are caused by multiple changes of ownership and sequential locations of use spread around the globe.
- A generally low awareness about the loss of resources, and missing economic recycling incentives due to low intrinsic value per unit. Nevertheless, the overall mass flows have a big impact on metal demand (Hagelüken and Meskers 2008).

- Lack of an appropriate recycling infrastructure for EOL management of complex products in many developing countries and emerging economies. In industrialized countries, many hibernating goods (products stored in drawers and closets and not yet discarded) and small devices that go into the trash bin (e.g., mobile phones) reduce significantly the recycling efficiencies.

- Recycling technologies that have not kept pace with complex and elementally diverse modern products.

Closed cycles are typical for many industrial goods, such as industrial machinery, tools, and process catalysts. Although the required recycling technology does not differ much from that 


\begin{tabular}{|c|c|c|c|c|c|c|c|c|c|c|c|c|c|c|c|c|c|}
\hline $\begin{array}{l}1 \\
\mathrm{H}\end{array}$ & & & & & & & & & & & & & & & & & $\begin{array}{c}2 \\
\mathrm{He}\end{array}$ \\
\hline $\mathrm{L}$ & $B E$ & & & & & & & & & & & $\begin{array}{l}5 \\
\text { B }\end{array}$ & $\begin{array}{l}6 \\
\mathrm{C}\end{array}$ & $\begin{array}{l}7 \\
\mathrm{~N}\end{array}$ & $\begin{array}{l}8 \\
0\end{array}$ & $\begin{array}{l}9 \\
F\end{array}$ & $\begin{array}{r}10 \\
\mathrm{Ne}\end{array}$ \\
\hline $\begin{array}{l}11 \\
\mathrm{Na}\end{array}$ & $\begin{array}{c}12 \\
\mathrm{Mg}\end{array}$ & & & & & & & & & & & $\begin{array}{l}13 \\
\mathrm{Al}\end{array}$ & $\begin{array}{l}14 \\
\mathrm{Si}\end{array}$ & $\begin{array}{l}15 \\
P\end{array}$ & $\begin{array}{c}16 \\
\mathrm{~S}\end{array}$ & $\begin{array}{l}17 \\
\mathrm{Cl}\end{array}$ & $\begin{array}{l}18 \\
\mathrm{Ar}\end{array}$ \\
\hline $\begin{array}{l}19 \\
\mathrm{~K}\end{array}$ & $\begin{array}{l}20 \\
\mathrm{Ca}\end{array}$ & $\begin{array}{l}21 \\
\text { Sc }\end{array}$ & $M$ & $\begin{array}{l}23 \\
\mathrm{~V}\end{array}$ & $\begin{array}{l}24 \\
\mathrm{Cr}\end{array}$ & $\begin{array}{l}25 \\
\mathrm{Mn}\end{array}$ & $\begin{array}{l}26 \\
\mathrm{Fe}\end{array}$ & $\begin{array}{l}27 \\
\text { Co }\end{array}$ & $\begin{array}{l}28 \\
\mathrm{Ni}\end{array}$ & $\begin{array}{l}29 \\
\mathrm{Cu}\end{array}$ & $\begin{array}{l}30 \\
\mathrm{Zn}\end{array}$ & $\mathrm{Ga}$ & $\mathrm{Ge}$ & As & $\begin{array}{l}34 \\
\text { Se }\end{array}$ & $\begin{array}{l}35 \\
\mathrm{Br}\end{array}$ & $\begin{array}{l}36 \\
\mathrm{Kr}\end{array}$ \\
\hline $\begin{array}{l}37 \\
\mathrm{Rb} \\
\end{array}$ & $\begin{array}{l}38 \\
\mathrm{Sr}\end{array}$ & $\begin{array}{l}39 \\
Y\end{array}$ & $\begin{array}{l}40 \\
\mathrm{Zr}\end{array}$ & $\begin{array}{l}41 \\
\mathrm{Nb}\end{array}$ & $\begin{array}{l}42 \\
\text { Mo }\end{array}$ & $\begin{array}{l}43 \\
\text { Tc }\end{array}$ & $\mathrm{Ru}$ & $\begin{array}{r}45 \\
\mathrm{Rh} \\
\end{array}$ & $\begin{array}{l}46 \\
\mathrm{Pd} \\
\end{array}$ & $\begin{array}{l}47 \\
\mathrm{Ag} \\
\end{array}$ & $\begin{array}{l}48 \\
\mathrm{Cd} \\
\end{array}$ & $\begin{array}{l}49 \\
\text { In }\end{array}$ & $\begin{array}{l}50 \\
\text { Sn }\end{array}$ & sb & $\begin{array}{l}52 \\
\mathrm{Te} \\
\end{array}$ & $\begin{array}{c}53 \\
1 \\
\end{array}$ & $\begin{array}{r}54 \\
\times e \\
\end{array}$ \\
\hline $\begin{array}{l}55 \\
\text { Cs }\end{array}$ & $\begin{array}{l}56 \\
\mathrm{Ba}\end{array}$ & * & $\begin{array}{l}72 \\
\mathrm{Hf}\end{array}$ & Ta & $\begin{array}{l}74 \\
W\end{array}$ & $\begin{array}{l}75 \\
\mathrm{Re}\end{array}$ & Os & $\begin{array}{l}77 \\
\text { Ir }\end{array}$ & $\begin{array}{l}78 \\
\mathrm{Pt}\end{array}$ & $\begin{array}{l}79 \\
\mathrm{Au}\end{array}$ & $\begin{array}{l}80 \\
\mathrm{Hg}\end{array}$ & 81 & $\begin{array}{l}82 \\
\mathrm{~Pb}\end{array}$ & 83 & $\begin{array}{l}84 \\
\text { Po }\end{array}$ & $\begin{array}{l}85 \\
\text { At }\end{array}$ & $\begin{array}{l}86 \\
\mathrm{Rn}\end{array}$ \\
\hline $\begin{array}{l}87 \\
\mathrm{Fr}\end{array}$ & $\begin{array}{l}88 \\
\mathrm{Ra}\end{array}$ & ** & $\begin{array}{c}104 \\
\text { Rf }\end{array}$ & $\begin{array}{l}105 \\
\mathrm{Db}\end{array}$ & $\begin{array}{c}106 \\
\mathrm{Sg}\end{array}$ & $\begin{array}{l}107 \\
\mathrm{Bh}\end{array}$ & $\begin{array}{l}108 \\
\mathrm{Hs}\end{array}$ & $\begin{array}{l}109 \\
\mathrm{Mt}\end{array}$ & $\begin{array}{l}110 \\
\text { Ds }\end{array}$ & $\begin{array}{l}111 \\
\mathrm{Rg}\end{array}$ & $\begin{array}{l}112 \\
\text { Uub }\end{array}$ & $\begin{array}{l}113 \\
\text { Uut }\end{array}$ & $\begin{array}{c}114 \\
\text { Uuq }\end{array}$ & $\begin{array}{l}115 \\
\text { Uup }\end{array}$ & $\begin{array}{l}116 \\
\text { Uuh }\end{array}$ & $\begin{array}{l}\text { (117) } \\
\text { (Uus) }\end{array}$ & $\begin{array}{l}118 \\
\text { Uuo }\end{array}$ \\
\hline
\end{tabular}

\begin{tabular}{|c|c|c|c|c|c|c|c|c|c|c|c|c|c|c|c|}
\hline * Lanthanides & 57 & 58 & 59 & 60 & 61 & 62 & 63 & 64 & 65 & 66 & 67 & 68 & 69 & 70 & 71 \\
& $\mathrm{La}$ & $\mathrm{Ce}$ & $\mathrm{Pr}$ & $\mathrm{Nd}$ & $\mathrm{Pm}$ & $\mathrm{Sm}$ & $\mathrm{Eu}$ & $\mathrm{Gd}$ & $\mathrm{Tb}$ & $\mathrm{Dy}$ & $\mathrm{Ho}$ & $\mathrm{Er}$ & $\mathrm{Tm}$ & $\mathrm{Yb}$ & $\mathrm{Lu}$ \\
\hline ** Actinides & 89 & 90 & 91 & 92 & 93 & 94 & 95 & 96 & 97 & 98 & 99 & 100 & 101 & 102 & 103 \\
& $\mathrm{Ac}$ & $\mathrm{Th}$ & $\mathrm{Pa}$ & $\mathrm{U}$ & $\mathrm{Np}$ & $\mathrm{Pu}$ & $\mathrm{Am}$ & $\mathrm{Cm}$ & $\mathrm{Bk}$ & $\mathrm{Cf}$ & $\mathrm{Es}$ & $\mathrm{Fm}$ & $\mathrm{Md}$ & No & Lr \\
\hline
\end{tabular}

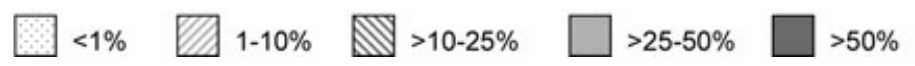

Figure 5 The periodic table of global average old scrap ratios (OSR) for 60 metals, with the individual metals categorized into one of five ranges. Unshaded entries indicate that no data or estimates are available or that the elements were not addressed in this study.

for consumer goods, the recycling efficiencies are usually much higher due to a high awareness of the involved stakeholders, economic recycling incentives, transparent and professional handling throughout the product life cycle, and a rather limited change of ownership and location of use.

The recycling metrics represent average current global-level estimates. These metrics vary from year to year due to changes in a number of underlying factors: metal use a product lifetime ago, share of different end-use sectors, product lifetimes, product composition, product weight, and recycling efficiencies (Van Schaik et al. 2004; Reuter et al. 2005; Müller et al. 2006; Reck et al. 2010). In addition, even though recycling rate statistics at the country level are sparse, it is clear that metals with low global recycling rates must also have low rates within individual countries. As concerns continue to rise about absolute availability, trade barriers, and other potential supply constraints, it is in the interest of all countries to enhance their longterm sustainability by increasing recycling rates and thereby retaining metals rather than discarding or dispersing them, as is often the case at present.

In practice, the effectiveness of recycling is a consequence of three related factors. The first is economics, because the net intrinsic value of the discarded materials must be high enough to justify the cost and effort of recycling. When that value is not present, incentives such as deposit fees or other cost subsidies, usually based on legal requirements, may make it so, at least at the consumer level. The second factor is technology: Do the design of the discarded product and the ways materials are joined or merged enable or inhibit available recycling processes? The final factor is societal: Has a habit of recycling been established? Do public campaigns promote recycling targets? Can legislation, recycling fees, or 
other recycling policies prove effective? To the degree that these factors are addressed, improved rates of reuse and recycling are likely. Many of these issues are discussed in detail by Graedel and Van der Voet (2010).

Policies involving recycled content goals are intended to provide an incentive for recycling. Some argue, however, that this metric is only of limited relevance for metals because, unlike materials such as paper or some plastics, the availability of secondary metals (new or old scrap) is limited due to the often long lifetimes of metals in use (Atherton 2007). One could argue that the intent of such policies could better be achieved by encouragement of a high OSR (i.e., the old scrap in the recycled content). Such an approach would provide an incentive to increase the EOLRR (i.e., increase the share of old scrap) and make fabrication processes more efficient (i.e., decrease the share of new scrap). In fact, many consider the EOL-RR to be the most important recycling metric (Recycling Project Team 2010).

A large research and data collection effort is needed in the case of many of the metals to locate missing information and to obtain more reliable recycling statistics. Measures of recycling performance are needed for informed policy directions and to evaluate the effects of public policy and societal performance. In addition, in-depth research is necessary to develop new recycling technologies and infrastructures for specific applications (especially emerging technologies). Nonetheless, it needs to be understood that due to the dissipative use of many metals and to fundamental thermodynamic limits (Castro et al. 2004; Van Schaik and Reuter 2004), it is not possible to recover everything, even in an optimized environment.

Despite the challenges of improving recycling rates, however measured, recycling generally saves energy and minimizes the environmental challenges related to the extraction and processing of virgin materials. The data presented in this report, and the discussions related to how the data are measured and how they might change over time given certain technological or societal approaches, provide information likely to be useful in moving society toward a more efficient level of resource utilization in the future.

\section{Acknowledgments}

This article is a substantially modified summary version of a report by the same title published by the Global Metal Flows working group of the International Panel on Sustainable Resource Management, United Nations Environment Programme. We thank the following additional workshop participants for their expert perspectives and contributions: Stefan Bringezu, Wuppertal Institute, Germany; Werner Bosmans, European Commission, Belgium; Ichiro Daigo, University of Tokyo, Japan; Kohmei Halada, NIMS, Japan; Seiji Hashimoto, NIES, Japan; Petra Mo, World Steel Association, Belgium; Susanne Rotter, Technical University of Berlin, Germany; Mathias Schluep, Swiss Federal Laboratories for Materials Science and Technology, Switzerland; Raymond Sempels, International Zinc Association, Belgium; Fritz Teroerde, ELG Metals, United States/Germany; George Varughese, Development Alternatives, India; Zheng Luo, Organisation of European Aluminium Refiners and Remelters, Germany. We are especially thankful to Christina Meskers, Umicore, Belgium, for her valuable contributions to the article.

We are grateful for comments on drafts of this report by J. Bullock (attorney), A. Carpentier (Eurometaux, Belgium), D. Fechner (Centre for Materials and Coastal Research, Germany), W. Heenan (Steel Recycling Institute, United States), A. Hlada (International Antimony Association, Belgium), A. Lee (International Copper Association, United States), R. Mishra (A-1 Specialized Services \& Supplies, United States), H. Morrow (International Cadmium Association, Belgium), C. Risopatron (International Copper Study Group, Portugal), M. Schlesinger (Missouri University of Science and Technology, United States), U. Schwela (Tantalum-Niobium International Study Center, Belgium), G. Servin (European Copper Institute, Belgium), and D. Smale (International Copper Study Group, International Nickel Study Group, and International Lead and Zinc Study Group, Portugal).

\section{Notes}

1. A metalloid is an element with properties intermediate between those of a metal and those of a nonmetal. 
2. This useful term is borrowed from the plastics recycling community.

3. This term was coined by Guinée and colleagues (1999).

4. The workshop was held in Brussels, Belgium, April 24-25, 2009. The attendees consisted of the authors of this article and those recognized in the Acknowledgments.

5. A base metal is a metal that oxidizes or corrodes relatively easily (e.g., iron, lead, zinc, and copper), in contract to noble or precious metals.

\section{References}

Atherton, J. 2007. Declaration of the metals industry on recycling principles. International Journal of Life Cycle Assessment 12: 59-60.

Bailey, R., B. Bras, and J. K. Allen. 2008. Measuring material cycling in industrial systems. Resources Conservation and Recycling 52(4): 643-652.

Castro, M. B. G., J. A. M. Remmerswaal, M. A. Reuter, and U. J. M. Boin. 2004. A thermodynamic approach to the compatibility of materials combinations for recycling. Resources, Conservation, and Recycling 43: 1-19.

Chancerel, P. and S. Rotter. 2009. Recycling-oriented characterization of small waste electrical and electronic equipment. Waste Management 29: 23362352.

Dubreuil, A., S. Young, J. Atherton, and T. Gloria. 2010. Metals recycling maps and allocation procedures in life cycle assessment. International Journal of Life Cycle Assessment 15: 621-634.

Eurometaux. 2006. Recycling rates for metals. :www.eurometaux.org/Publications/

BrochuresandLeaflets.aspx. Accessed August 2010.

Gaustad, G., E. Olivetti, and R. Kirchain. 2010. Design for recycling: Evaluation and efficient alloy modification. Journal of Industrial Ecology 14(2): 286-308.

Graedel, T. E. and E. Van Der Voet, eds. 2010. Linkages of sustainability. Cambridge, MA: MIT Press.

Guinée, J. B., J. C. J. M. van den Bergh, J. Boelens, P. J. Fraanje, G. Huppes, P. P. A. A. H. Kandelaars, T. M. Lexmond, et al. 1999. Evaluation of risks of metal flows and accumulation in economy and environment. Ecological Economics 30: 47-65.

Hagelüken, C. 2007. The challenge of open cycles. In R'07, 8th world congress, edited by L. M. Hilty et al. CD-ROM. Stuttgart, Germany: Fraunhofer Institut Zuverlässinkeit und Mikrointegration.

Hagelüken, C. and C. E. M. Meskers. 2008. Mining our computers. In Electronics goes green Con- ference, 2008, edited by H. Reichl et al., pp 585-590. Lisbon, Portugal: International Copper Study Group.

International Copper Study Group. 2004. End of life vehicles. ICSG Information Circular 13. www.icsg.org/images/stories/pdfs/ icsginfocircularelv.pdf. Accessed 7 December 2010.

ISO. 2006. ISO 14044:2006(E): Environmental management_-Life cycle assessment_Requirements and guidelines. Geneva, Switzerland: ISO.

Meskers, C. E. M. 2008. Coated magnesium: Designed for sustainability. $\mathrm{PhD}$ thesis, Delft University of Technology, Delft, the Netherlands.

Müller, D. B., T. Wang, B. Duval, and T. E. Graedel. 2006. Exploring the engine of anthropogenic iron cycles. Proceedings of the National Academy of Sciences of the United States of America 103(44): 16111-16116.

Reck, B. K. and R. B. Gordon. 2008. Nickel and chromium cycles: Stocks and flows project Part IV. JOM 60(7): 55-59.

Reck, B. K., M. Chambon, S. Hashimoto, and T. E. Graedel. 2010. Global stainless steel cycle exemplifies China's rise to metal dominance. Environmental Science EO Technology 44(10): 3940-3946.

Recycling Project Team. 2010. Personal communication from the Recycling Project Team, Eurometaux, Brussels, Belgium, 4 November.

Reuter, M. A., U. M. J. Boin, A. Van Schaik, E. Verhoef, K. Heiskanen, Y. Yongxiang, and G. Georgalli, eds. 2005. The metrics of material and metal ecology. Developments in mineral processing, Vol. 16. Amsterdam: Elsevier Science.

Sibley, S. F. 2004. Flow studies for recycling metal commodities in the United States. Reston, VA, USA: U.S. Geological Survey.

Sibley, S. F. and W. C. Butterman. 1995. Metals recycling in the United States. Resources Conservation and Recycling 15(3-4): 259-267.

Steel Recycling Institute. 2010. Steel recycling rate graphs. www.recycle-steel.org/PDFs/ 2008Graphs.pdf. Accessed 7 December 2010.

Van Schaik, A. 2004. Theory of recycling systems applied to car recycling. Ph.D. dissertation, Delft University of Technology, Delft, the Netherlands.

Van Schaik, A., and M. A. Reuter. 2004. The timevarying factors influencing the recycling rate of products. Resources Conservation and Recycling 40(4): 301-328.

Van Schaik, A., M. A. Reuter, and K. Heiskanen. 2004. The influence of particle size reduction and liberation on the recycling rate of end-of-life vehicles. Minerals Engineering 17: 331-347. 


\section{About the Authors}

Thomas Graedel is the Clifford R. Musser Professor of Industrial Ecology and Barbara Reck is an associate research scholar at the School of Forestry \& Environmental Studies at Yale University in New Haven, Connecticut, USA. Julian Allwood is a senior lecturer in engineering at Cambridge University in Cambridge, UK. Jean-Pierre Birat is sustainability coordinator with Arcelor-Mittal, in Maizieres-les-Metz, France. Matthias Buchert is head of information and enterprises with the Öko Institut, in Darmstadt, Germany. Christian Hagelüken is head of the Department for Business Development and Market Research with Umicore Precious Metals Refining in Hanau, Germany. Scott F. Sibley is chief of mineral commodities, National Minerals Information Center, with U.S. Geological Survey (USGS) in Herndon, Virginia, USA. Guido Sonnemann is program officer for the Division of Technology, Industry, and Economics with the United Nations Environment Programme in Paris, France.

\section{Supporting Information}

Additional Supporting Information may be found in the online version of this article:

Supporting Information S1: This Supporting Information includes four sections on detailed review and resolution of recycling statistics, including ferrous metals (S1-1), nonferrous metals (S1-2), precious metals (S1-3), and specialty metals (S1-4). This Supporting Information also defines the system in figure 2 from the main article (S1-5) and discusses scrap use in metal production (S1-6).

Please note: Wiley-Blackwell is not responsible for the content or functionality of any supporting information supplied by the authors. Any queries (other than missing material) should be directed to the corresponding author for the article. 